\title{
Ascomycetes from central and northern Labrador
}

\author{
SEPPO HUHTINEN
}

HUHTINEN, S. 1982: Ascomycetes from central and northern Labrador. - Karstenia 22: 1 -8.

A list of 44 ascomycetous fungi, mainly Pezizales and Helotiales is presented from a little known area of Labrador, Canada. Two species are reported as new to North America: Gyromitra cf. gigas (Krombh.) Cooke and Cistella grevillei (Berk.) Raschle. The occurrence of Hyaloscypha lectissima (Karst.) Raitv. in North America needs further study. The known range of many of the species is extended.

Seppo Huhtinen, Department of Biology, University of Turku, SF-20500 Turku 50, Finland.

The Arctic and Subarctic still contain many mycologically poorly explored areas. Inventory of the fungi in these areas provides a basis for understanding ecological aspects of circumpolar mycology. Except for Kallio's (1980) preliminary work, there are only scattered references to the fungi of central and northern parts of Labrador (e.g. Groves \& Hoare 1954, Bigelow 1959, Heikkilä \& Kallio 1969, Kankainen 1969, Groves \& Elliott 1971, Elliott \& Kaufert 1974). The present paper deals mainly with species belonging to the Pezizales and Helotiales in that area. This is the first in a series of studies from the Canadian North. The next papers, now being prepared, will deal mainly with larger fungi from the same collection area.

\section{Material and methods}

The collections date back to 1963, 1967, 1978 and 1979, when the Kevo Subartic Research Institute (Finland) carried out various projects in Labrador. Most of the collections were made near Schefferville $\left(54^{\circ} 49^{\prime} \mathrm{N}, 66^{\circ} 48^{\prime} \mathrm{W}\right)$, but there is also some material from Fort Chimo $\left(58^{\circ} 06^{\prime} \mathrm{N}, 68^{\circ} 24^{\prime} \mathrm{W}\right)$, Esker $\left(53^{\circ} 52^{\prime}\right.$ $\left.\mathrm{N}, 66^{\circ} 25^{\prime} \mathrm{W}\right)$, Labrador City $\left(52^{\circ} 54^{\prime} \mathrm{N}, 66^{\circ} 54^{\prime} \mathrm{W}\right)$ and Churchill Falls $\left(53^{\circ} 36^{\prime} \mathrm{N}, 64^{\circ} 18^{\prime} \mathrm{W}\right)$. The localities lie in the provinces of Quebec and Newfoundland. Schefferville and Fort Chimo are situated in the Subarctic, the former at the southern and the latter at the northern limit of Hustich's (1949) forest-tundra zone. The other, more southern, sites are situated in the true taiga. The collections were made by the following persons: Heli Heikkilä (H.H.), Seppo Huhtinen (S.H.), Paavo Kallio (P.K.), Esteri Kankainen (E.K.), Lasse Kosonen (L.K.) and Yrjö Mäkinen (Y.M.).
The material was studied microscopically, using $\times$ 1500 magnification. The mounting media were: Melzer's Reagent, lactophenol or the latter mixed with cotton blue (Hollborn, Leipzig). The surface ornamentation is included in the spore measurements, if not otherwise stated. The drawings were made with the aid of a camera lucida. The material is deposited in TUR. The list of species mainly follows the classification by Korf (1973).

\section{List of species}

\section{Loculoascomycetes \\ Hysteriaceae}

Lophium mytilinum (Pers.) Fr.

Que. Schefferville, Attikamagen Lake, on Abies balsamea, 500 m, 5.VIII. 1967 Y.M. 67/1431b.

\section{Discomycetes \\ Pezizales \\ Sarcosomataceae}

Pseudoplectania nigrella (Fr.) Fuck.

Nfld. Schefferville, Marble Lake, 450 m, 13.VII. 1967 E.K.; Churchill Falls, on rotten wood, 28.VII.1968 P.K. - Oue. Schefferville, E of airport, rotten stub, $550 \mathrm{~m}$, 8.VII. 1967 E.K.

\section{Pezizaceae}

Peziza badia Mérat

Nfld. Schefferville, Ruth Ridge, sandy road, $600 \mathrm{~m}$, 2.VIII. 1967 P.K.; Slimy Lake, sandy road, 550 m, 21.VIII. 1979 S.H. \& L.K. - Que. Schefferville, bog $\mathrm{N}$ of town, ditch bank, $550 \mathrm{~m}$, 4.VIII. 1967 E.K. 
The spores show the typical, partly reticulate ornamentation. Also reported by Elliott \& Kaufert (1974) from Goose Bay.

Peziza badioconfusa Korf - Fig. 1

Que. Schefferville, Attikamagen Lake, mossy roadside ground, 500 m, 5.VIII.1967 Y.M. 67/1437a, 67/1439.

Spores ca. $18.3 \times 8.7 \mu \mathrm{m}$, their ornamentation consisting of irregular warts. The collections lack any mention of wood as substrate, and the specimens also lack the violaceous base mentioned earlier, e.g. by Schumacher (1979). However, the spores are characteristic of the species and the fruiting time is within the range given by Elliott \& Kaufert (1974) and Ginns (1980).

\section{Peziza repanda Pers.}

Que. Fort Chimo, village, 30 m, 26.VII.1967 E.K.

Disc medium brown, excipulum showing layers as in Rifai (1968, Fig. 245). Spores smooth, 13-15 $\times$ $8-9 \mu m$.

Peziza limnaea Maas Geest. -Fig. 2

Nfld. Schefferville, Astray Lake, near a brook, $550 \mathrm{~m}$, 4.VIII. 1967 Y.M. 67/1393. - Que. Fort Chimo, village, sandy ground, 30 m, 26.VII. 1967 E.K.; Whale's Head, sandy river bank, 90 m, 29.VII.1967 E.K.; Highfall Greek, sandy beach, 50 m, 2.VIII. 1967 H.H.; Old Fort Chimo, 10 m, 31.VII. 1967 E.K.

Apothecia $0.4-2.0 \mathrm{~cm}$ across, discoid to shallowly cupulate, hymenium violaceous brownish, black when dried. Asci $280-360 \times 15-18 \mu \mathrm{m}$, regularly tapering, strongly J+. Spores narrowly ellipsoid, $20-22 \times 9-11 \mu \mathrm{m}$, with two usually unequal oil drops. Ornamentation consisting of separate, $0.5-\mu \mathrm{m}$-high warts and short ridges. Paraphyses septate, slightly clavate, adherent at tips.

\section{Peziza praetervisa Bres.}

Nfld. Schefferville, Marble Lake cabin, fire place, $450 \mathrm{~m}$, 11.VII.1967 H.H. \& E.K.; Marble Lake, dolomite area, 450 m, 12.VII.1967 Y.M. 67/558; Esker, burned wood, subalpine region, 20.VII.1967 Y.M. 67/879.

\section{Helvellaceae}

\section{Gyromitra ambigua (Karst.) Harmaja}

Nfld. Schefferville, Lejeune Lake, on mossy branch, $500 \mathrm{~m}$, 24.VIII.1979 S.H. \& L.K. - Que. Schefferville, John Lake, on the ground, $550 \mathrm{~m}$, 28.VIII.1979 S.H. \& L.K.; Peter's Creek, by a stump, 500 m, 13.VIII.1979 S.H. \& L.K.

Growing in mixed spruce forest. Harmaja's (1969) observation from Fennoscandia ('..perhaps always found near pines..') does not apply to the Schefferville area, which lacks pine. The collections are typical and the determinations were confirmed by Dr. Harmaja.
Gyromitra esculenta (Fr.) Fr. coll.

Nfld. Between Churchill Falls and Twin Falls, 27.VI.1963 P.K.

This collection has mostly subfusiform spores, measuring ca. $23-26 \times 9-10 \mu \mathrm{m}$, and according to Dr. Harmaja it represents type II in Harmaja (1979). Groves \& Elliott (1971) report G. esculenta from Goose Bay.

Gyromitra cf. gigas (Krombh.) Cooke - Fig. 3 Nfld. Esker, on bare ground, upper subalpine region, 20.VII.1967 Y.M. 67/903.

The spores, ca. $28-31 \times 11-12 \mu \mathrm{m}$ (perispore excluded), have an ornamentation also visible in sideview ( $\times 1500$, cotton blue). The spore apiculi are conspicuous and almost always present. The paraphyses are clavate to subcapitate, rarely exceeding 10 $\mu \mathrm{m}$ in width at their apices.

According to Harmaja (1973), the true G.gigas has not yet been observed in North America. This collection comes very close to this species, as was also confirmed by Dr. Harmaja.

Helvella corium (Weberb.) Massee

Que. Schefferville, NE of airport, sandy roadside, $500 \mathrm{~m}$, 8.VII.1967 Y.M. 67/300; bog N of airport, $550 \mathrm{~m}, 10$.VII. 1967 E.K.; airport, on filling, 500 m, 20.VII.1978 P.K.

The amount of white 'warts' on the outside of the apothecium varies even within a single collection. Kallio (1980) reports two collections from Schefferville.

\section{Helvella palustris Peck}

Nfld. Schefferville, Astray Lake, muddy bog depression, 12.VIII.1979 S.H. \& L.K.

The habitat and the non-lacunose stipe are characteristic of this species, which is evidently conspecific with $H$. philonotis Diss., as pointed out by Weber (1972).

Rhizina undulata Fr.

Nfld. Esker, burned area, 550-700 m, 20.VII.1967 H.H. \& E.K.; burned area, 600 m, 20.VII. 1967 E.K. \& Y.M.

\section{Pyronemataceae}

Aleuria aurantia (Fr.) Fuck.

Nfld. Labrador City, SE of Wabush, lichen woodland, 19.VIII.1963 P.K.

Geopyxis carbonaria (Pers.) Sacc.

Nfld. Schefferville, Marble Lake cabin, fire place, $450 \mathrm{~m}$, 11.VII.1967 H.H. \& E.K.; Marble Lake, island E of cabin, old felt boot?, $450 \mathrm{~m}, 12$.VII. 1967 Y.M. 67/533.

Medullary excipulum up to ca. $150 \mu \mathrm{m}$ thick. Ectal excipulum of textura globulosa.

Figs. 1-8. Pezizales, scale $50 \mu \mathrm{m}$. - 1: Peziza badioconfusa. - 2: Peziza limnaea. - 3: Gyromitra cf. gigas, spores and tips of paraphyses. - 4: Octospora sp. a) apothecia, b) outer excipulum, c) hypha of 'subiculum', d) paraphyses, e) spores. - 5: Lamprospora ovalispora. - 6: Scutellinia cf. ampullacea. - 7: Scutellinia cejpii. - 8: Octospora humosa. 
Karstenia 22. 1982
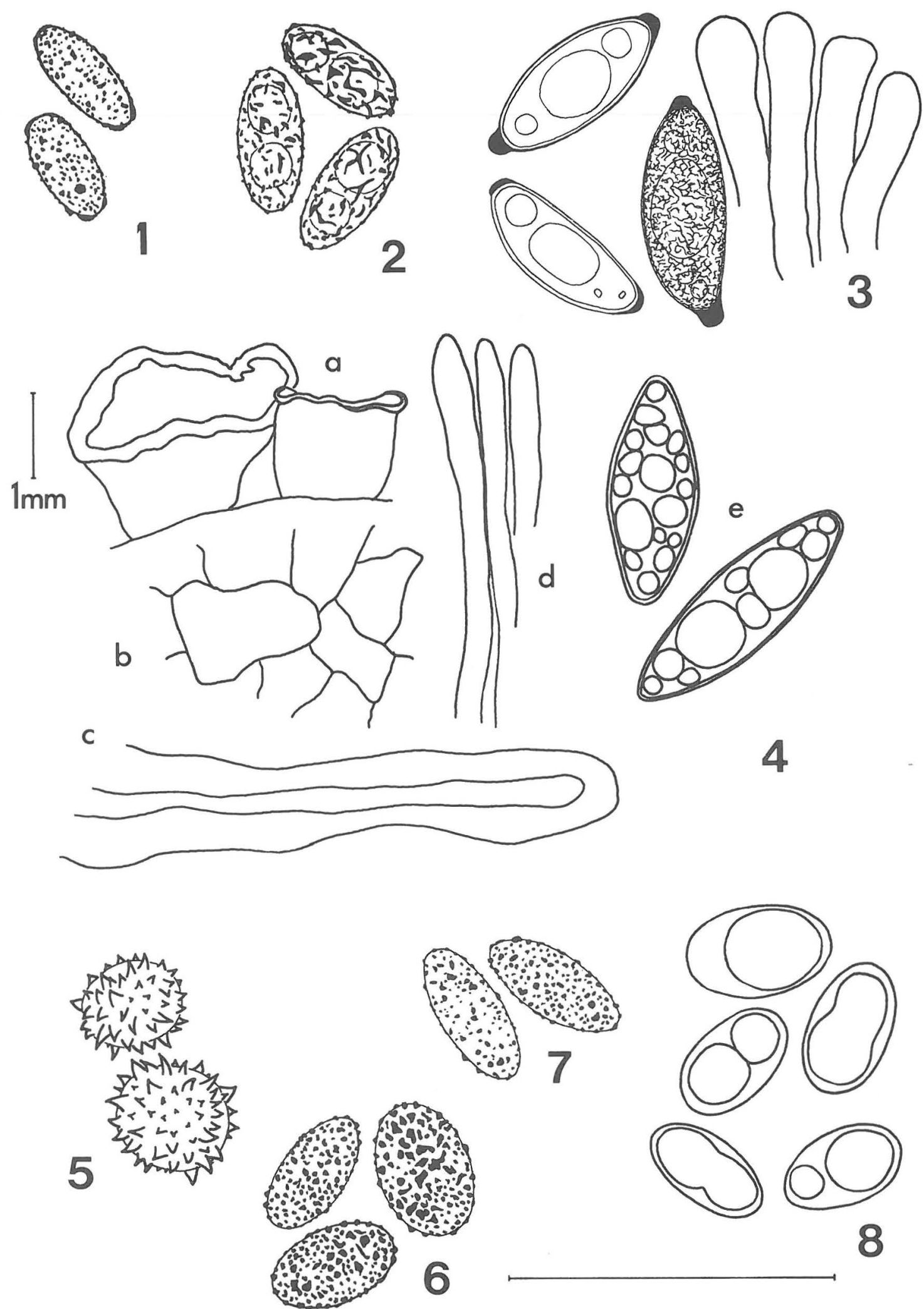
Lamprospora ovalispora (Svrček \& Kub.) Eckbl. -Fig. 5

Nfld. Churchill Falls, peaty soil, 14.VII.1968 P.K.

Spores $16-19 \times 14-17 \mu \mathrm{m}$ (ornamentation excluded), subglobose to broadly elliptical, spiny, the spines reaching $4 \mu \mathrm{m}$ in height. A few of the spores have one de Bary bubble.

According to Schumacher (1979), this species is one of the most common operculate discomycetes in Norway, usually occurring on muddy soils.

\section{Leucoscypha vivida (Nyl.) Eckbl.}

Nfld. Schefferville, Elizabeth Lake, on Polytrichum, $550 \mathrm{~m}$, 17.VIII.1979 S.H. \& L.K.; Esker, village, sandy soil, 500 m, 19.VII.1967 E.K. - Que. Fort Chimo, Old Fort Chimo, on Polytrichum, $50 \mathrm{~m}, 31$.VII. 1967 H.H.

Hairs of the ectal excipulum $200-300 \times 5-7 \mu \mathrm{m}$, septate, blunt and thick-walled $(1 \mu \mathrm{m})$, as stated by Eckblad (1968). Spores $21-26 \times 13-14 \mu \mathrm{m}$, exactly as in Rifai (1968, Fig. 166).

In two of the collections the apothecia were clearly growing on Polytrichum (cf. Eckblad 1968). According to Rifai (1968), Patella albocincta (Berk. \& Curt.) Seaver is conspecific with the present species.

Melastiza chateri (W.G. Smith) Boud.

Que. Schefferville, Peter's Creek, along a path in lichen woodland, 500 m, 13.VIII.1979 S.H. \& L.K.

\section{Octospora sp.} -Fig. 4 Nfld. Schefferville, Astray Lake, muddy brookshore with Marchantia polymorpha, $550 \mathrm{~m}$, 4.VIII.1967 Y.M. 67/1375, 67/1375a.

Apothecia $1-3 \mathrm{~mm}$ in diam., gregarious. Hymenium orange-red, outside paler, margin indistinctly serrate, composed of cylindrical-clavate cells. The anchoring hyphae, forming a white subiculum-like, conspicuous mycelial growth, are $12-16(-27) \mu \mathrm{m}$ thick with $3-5(-10) \mu \mathrm{m}$ thick gelatinized walls. Ectal excipulum of textura angularis, measuring 15-20 $\mu \mathrm{m}$ across. Medullary excipulum of textura intricata. Asci $200-220 \times 16-20 \mu \mathrm{m}$, spores uniseriate, fusoid, $35-40 \times 12-13 \mu \mathrm{m}$, usually with two large and numerous small oil globules. Spore ends not with thickened wall at maturity. Paraphyses slender, slightly enlarged above (up to $6 \mu \mathrm{m}$ ), not exceeding the asci.

Some of the characters used by Rifai (1968) to separate the genus Inermisia were discussed by Svrcek (1969). He drew attention to the fusoid spores, 'subiculum' and medullary excipulum composed of textura intricata. However, in this material the margin of receptacle is composed of cylindrical-clavate cells and the spore ends are not thickened.

The large, strictly uniseriate spores and less enlarged paraphyses separate the present material from Octospora coccinea (Crouan) van Brummelen (i.e. Dennis \& Itzerott 1973, Seaver 1961a).
Octospora humosa (Fr.) Dennis

- Fig. 8

Nfld. Labrador City, Wabush airstrip, clayey roadside with Polytrichum piliferum, 7.VIII.1967 Y.M. 67/1476, 67/1478. - Que. Fort Chimo, near hospital, clayey brook bank, 20 m, 29.VII.1967 Y.M. 67/1212; Schefferville, bog N of airport, 550 m, 10.VII. 1967 H.H. \& E.K., 4.VIII. 1967 Y.M.

Apothecia large, $0.2-1.3 \mathrm{~cm}$ across. Spores uniseriate at all stages, $19-21(-22) \times 10.5-11.5 \mu \mathrm{m}$, with broadly rounded ends and $1-2$ oil globules.

Polytrichum can be found in all but one of the collections. The variation in guttulation, present in this material also, is discussed in Dennis \& Itzerott (1973) and Itzerott (1977).

Scutellinia cf. ampullacea (Limm.) Kuntze -Fig. 6 Que. Schefferville, bog N of airport, $550 \mathrm{~m}$, 4.VIII. 1967 H.H.; Peter's Creek, along a path in lichen woodland, 500 m, 13.VIII.1979 S.H. \& L.K.

The material is tentatively referred to this species. The reddish-orange, terricolous apothecia are up to $13 \mathrm{~mm}$ in diameter. The rooting hairs are short, measuring $200-300(-500) \mu \mathrm{m}$, but they are narrow $(20$ $\mu \mathrm{m})$ at their base. The spores, $18-24 \times 11-13 \mu \mathrm{m}$, have a variable ornamentation of discrete to confluent warts up to $1(-1.5) \mu \mathrm{m}$ in height.

Scutellinia cejpii (Vel.) Svrček -Fig. 7 Nfld. Labrador City, Wabush airfield, sandy ground, 7.VIII. 1967 Y.M. 67/1477.

This species has recently been discussed by Schumacher (1979). As pointed out by him, S. cejpii is characterized by its narrow spores and short rooting hairs. In the present material the hairs reach a length of $300 \mu \mathrm{m}$. The spores are narrowly ellipsoidal, $21-$ $25 \times 10-12 \mu \mathrm{m}$, multiguttulate, with large irregularly distributed warts (cf. Denison 1959).

Scutellinia scutellata (Fr.) Lamb.

Nfld. Schefferville, Astray Lake, 550 m, 4.VIII.1967 Y.M. 67/1388, 67/1390, 67/1391, 67/1395; Marble Lake, dolomite area, $450 \mathrm{~m}, 12$.V1I.1967 Y.M. 67/554, 67/557; Marble Lake cabin, $450 \mathrm{~m}$, 11.VII.1967 H.H. \& E.K.; Churchill Falls, 29.VII.1968 P.K.; Esker, Menihek Lake, 500 m, 22.VII. 1967 Y.M. 67/987; burned area, $600 \mathrm{~m}, 20$.VII. 1967 Y.M. 67/885; beaver dam, $550 \mathrm{~m}$, 20.VII.1967 E.K. - Que. Fort Chimo, Highfall Creek, sandy river shore, $50 \mathrm{~m}, 2$.VIII. 1967 H.H. \& E.K.; Schefferville, sandy yard, 550 m, 4.VIII. 1967 Y.M. 67/1408; bog N of airfield, rotten wood,4.VIII. 1967 Y.M. 67/1356; on swamp mosses, 4.VIII.1967 Y.M. 67/1355; Attikamagen Lake, mossy tree trunk, 500 m, 5.VIII. 1967 Y.M. 67/1436.

Helotiales

Geoglossaceae

Neolecta vitellina (Bres.) Korf \& Rogers

Que. Schefferville, John Lake, solitary on a mossy trunk, $550 \mathrm{~m}, 30$.VIII.1979 S.H. \& L.K.

Asci $60-88 \times 5.5 \mu \mathrm{m}$, some filled with conidia. These characters separate this species from $N$. irregularis (Peck) Korf \& Rogers (Redhead 1977). 

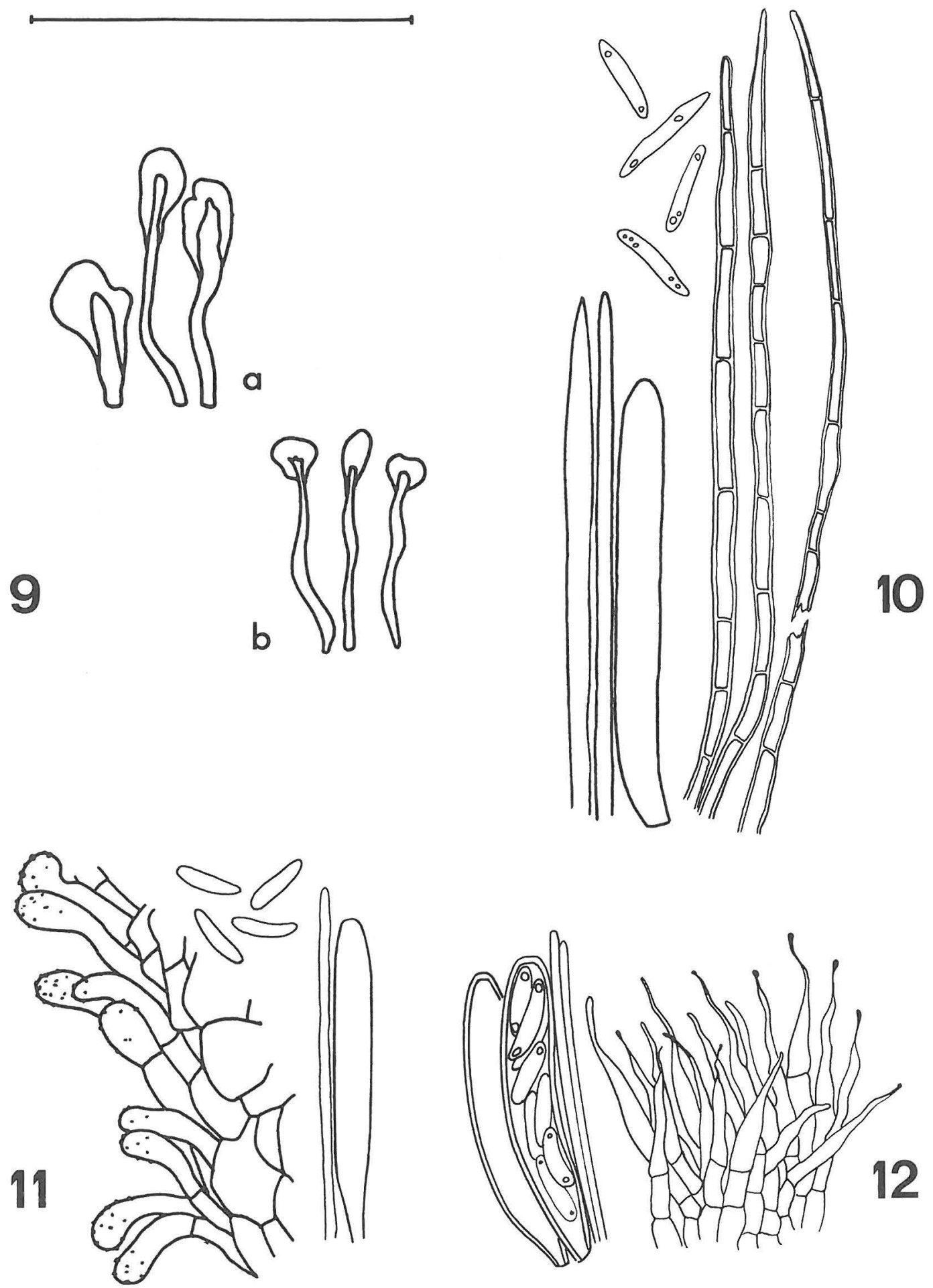

Figs. 9-12. Helotiales, scale $50 \mu \mathrm{m}$. - 9: Apothecia of Spathularia drawn from dried material, $\times 1$, a) S. rufa, b) S. flavida. - 10: Albotricha albotestacea, paraphyses, ascus, spores and hairs. - 11: Cistella grevillei, hairs and outer excipulum, spores, ascus and paraphyse. - 12: Hyaloscypha cf. lectissima, asci, spores, paraphyses and hairs from apothecial margin. 
Spathularia rufa (Pers.) Steud.

-Fig. 9

Nfld. Schefferville, Astray Lake, wet, mossy ground, $550 \mathrm{~m}$, 4.VIII.1967 Y.M. 67/1374; Astray Lake, rich Picea glauca forest, 12.VIII.1979 S.H. \& L.K.; Astray Lake, along a brook, 550 m, 4.VIII.1967 E.K., P.K. 87.

Fruit bodies gregarious, $5-7 \mathrm{~cm}$ high. Hymenial part ca. $1-3 \mathrm{~cm}$, brownish yellow when dried, strongly decurrent. Stipe greyish, darker than the hymenium. The grey color of the stipe is due to a loose structure covering the brown color. Spores ca. $1.7 \mu \mathrm{m}$ thick.

The occurence of $S$. rufa in North America has earlier been noted by Ohenoja (1975). The present material fits well with the description given by Ohenoja (1975), although the difference in spore width between $S$. rufa and $S$. flavida was not so clear (50 measurements) as in her material. E. Ohenoja has checked part of the material. The nomenclature of $S$. rufa is discussed by Ohenoja \& Isoviita (1981).

Spathularia flavida Fr. -Fig. 9 Que. Schefferville, Dolly Lake, in moss carpet, $550 \mathrm{~m}$, 14.VIII.1979 S.H. \& L.K.; $20 \mathrm{~km} \mathrm{~W}$ of town, $600 \mathrm{~m}, 26$. VIII.1979 S.H. \& L.K.

Hymenial part scarcely decurrent; almost discoid in the Dolly Lake collection, bright yellow when dried. Stipe whitish, lighter than hymenium.

\section{Hyaloscyphaceae}

Albotricha albotestacea (Desm.) Raitv. - Fig. 10 Que. Fort Chimo, Old Fort Chimo, on dead Elymus culms, $10 \mathrm{~m}, 31$. VII. 1967 E.K.

Apothecia subsessile, cupuliform, 0.2-0.3(-0.7) $\mathrm{mm}$ across. Excipulum light ochraceous. Disc light yellowish, concealed by white hairs when dry. Hairs tapering to an acute-subacute tip, 6-8(-11) -septate, smooth, $100-150 \times 2-3 \mu \mathrm{m}$, walls $0.6-0.7 \mu \mathrm{m}$ thick. Asci J+, 50-60 $\times 6-7 \mu \mathrm{m}$, tip conical. Spores biseriate, $10-13(-16) \times 1.5-2.5 \mu \mathrm{m}$, cylindrical-fusoid-inequilateral, with small oil globules. Paraphyses lanceolate, $2.5-4.5 \mu \mathrm{m}$ wide, exceeding the asci by $10-15 \mu \mathrm{m}$.

The determination is mainly based on hair characters. The closely related species $A$. acutipila (Karst.) Raitv. has thin-walled hairs. Consideration of the other characters given for these two species by Dennis (1949) and Raitviir (1970) suggests that the present material is intermediate. The excipulum is colored, however, although the reddish tinge is lacking in dry material.

Cistella grevillei (Berk.) Raschle - Fig. 11 Nfld. Schefferville, Astray Lake, on Heracleum maximum, $550 \mathrm{~m}, 4$.VIII. 1967 Y.M. 67/1367.

Apothecia sessile, pale yellowish, 0.5-1.0 mm across. Ectal excipulum with cylindrical to capitate, up to $5 \mu \mathrm{m}$ wide, $0-2$-septate hairs, minutely granulated at the apex. Hairs usually emerging from the excipulum with an outward curve. Asci $40-45 \times 6-7$ $\mu \mathrm{m}$. Spores mostly fusoid, aseptate, $7-10 \times 1.8-2$ $\mu \mathrm{m}$. Paraphyses cylindrical, up to $2 \mu \mathrm{m}$ in diameter, exceeding the asci by only $3-5 \mu \mathrm{m}$.

According to Raschle (1978), this species varies greatly in ascus length. The closely related $C$. tenuicula (Karst.) Raschle has longer spores $(18-23 \mu \mathrm{m}) . C$. grevillei is new to North America and should be sought on dead herbaceous stems.

Dasyscyphus bicolor (Fr.) Fuck.

Nfld. Schefferville, Ruth Ridge, on Alnus, 600 m, 9.VII.1967 E.K., on Picea mariana, Y.M. 67/325, on Ribes triste, Y.M. 67/327; Marble Lake, 450 m, 13.VII.1967 E.K., 12.VII. 1967 E.K. \& H.H.

Dasyscyphus papyraceus (Karst.) Sacc.

Nfld. Schefferville, Marble Lake, on Alnus twigs, $450 \mathrm{~m}$, 13.VII.1967 E.K.

Apothecia long-stalked, white with a yellowish hymenium, covered by hyaline, thin-walled hairs up to $70 \mu \mathrm{m}$ long. Asci short, 30-35 $\mu \mathrm{m}$ long. Spores minute, fusoid, $4 \times 1 \mu \mathrm{m}$. Paraphyses exceeding the asci by $10-15 \mu \mathrm{m}$, lanceolate, $2-2.5 \mu \mathrm{m}$ broad.

Dasyscyphus sulphurellus (Peck) Sacc.

Nfld. Schefferville, Marble Lake, 450 m, 2.VII.1967 H.H. \& E.K. (two collections); Astray Lake, $550 \mathrm{~m}, 4$.VIII. 1967 Y.M. 67/1397.

Hairs thick-walled, multiseptate at 5-7 $\mu \mathrm{m}$ intervals, minutely granulate, with abundant apical crystals.

According to Nannfeldt (1942), Dennis (1949) and Raitviir (1970), this species is restricted to Myrica gale (Gale palustris). Seaver (1961b) reports only rotten wood as substrate. The present material consists of numerous apothecia mostly growing on Myrica gale. There are, however, some twigs apparently not belonging to Myrica gale, but this should be verified microscopically.

Dasyscyphus virgineus (Fr.) Fuck.

Nfld. Schefferville, Marble Lake, on Alnus catkin scales, 450 m, 12.VII. 1967 H.H. \& E.K. - Que. Fort Chimo, Highfall Creek, on Alnus catkin scales, 50 m, 2.VIII.1967 E.K.

Attention should be paid to the paraphyses and hairs when separating $D$. virgineus and $D$. brevipilus Le Gal. The present material has up to $120 \mu \mathrm{m}$ long (mostly $80-100 \mu \mathrm{m}$ ) hairs and $2.5-3.0(-4.0 \mu \mathrm{m})$ wide, lanceolate paraphyses. However, they exceed the asci by only about $10 \mu \mathrm{m}$.

Hyaloscypha cf. lectissima (Karst.) Raitv. - Fig. 12 Nfld. Schefferville, Astray Lake, cortex of Alnus, $550 \mathrm{~m}$, 4.VIII.1967 Y.M. 67/1402.

Apothecia in large swarms, subsessile to sessile, $0.1-0.2 \mathrm{~mm}$ across, greyish when fresh, brownish in dry condition, margin fringed with whitish, aseptate hairs, measuring $20-30 \times 2-3 \mu \mathrm{m}$. The hairs narrowing rather abruptly to a flexuous tip, often with a little knob. Asci $40-50 \times 7-8 \mu \mathrm{m}$, stalk ill-defined. Spores $8-11 \times 2-2.5 \mu \mathrm{m}$, cylindrical-fusoid, often 
curved, with two oil globules. Paraphyses filiform, 1.5 $\mu$ m thick.

The collection is tentatively referred to $H$. lectissima. Karsten (1868) described the apothecia as yellowish and growing on cortex of Salix phylicifolia. The present material is also slightly hairier than the isolectotype (Herb. Karst. 590, H).

Lachnellula agassizii (Berk. \& Curt.) Dennis

Nfld. Schefferville, Marble Lake, 450 m, 11.VII.1967 Y.M. 67/480; Esker, Menihek Lake, 500 m, 22.VII.1967 Y.M. 67/968; Churchill Falls, 28.VII.1968 P.K. - Que. Schefferville, John Lake, 550 m, 30.VIII.1979 S.H. \& L.K.; Attikamagen Lake, 500 m, 5.VIII. 1967 Y.M. 67/1428, 67/1431c.

All the collections are from Abies balsamea. The species is apparently widely distributed and has also been reported from Goose Bay by Groves \& Hoare (1954).

Lachnellula arida (Phill.) Dennis

Nfld. Churchill Falls, on conifer, 28.VII.1968 P.K. - Que. Schefferville, Attikamagen Lake, on Picea glauca, $500 \mathrm{~m}$, 5.VIII. 1967 Y.M. 67/1429.

The broadly ellipsoidal spores, $6-7 \times 3-4 \mu \mathrm{m}$, separate this species from L. flavovirens (Bres.) Dennis, which has not yet been recorded from North America (cf. Dharne 1965).

Lachnellula occidentalis (Hahn \& Ayers) Dharne

Que. Fort Chimo, Highfall Creek, on Larix, $50 \mathrm{~m}$, 2.VIII. 1967 H.H.; Schefferville, Attikamagen Lake, on Larix, 500 m, 5.VIII. 1967 E.K.; $N$ of airfield, on Larix, 500 m, 4.VIII. 1967 Y.M. 67/1357.

The monilioid paraphyses figured in Dharne (1965) could be observed only in the collection from Attikamagen Lake.

Lachnellula suecica (Fuck.) Nannf.

Nfld. Schefferville, Ruth Lake, 600 m, 9.VII.1967 E.K., Y.M. 67/324, 67/348; NW of cemetery, 9.VII.1967 Y.M. 67/411; Esker, village, 500 m, 19.VII.1967 E.K., 23.VII.1967 E.K.; Tamarack River bridge, 500 m, 19.VII.1967 Y.M. 67/854. - Que. Schefferville, Attikamagen Lake, $500 \mathrm{~m}$, 5.VIII.1967 E.K., Y.M. 67/1430; N of airport, 4.VIII.1967 Y.M. 67/1358; Lac Vacher, 500 m, 18.VII.1967 Y.M. 67/989, 67/994; Dolly Ridge, 8.VII.1967 Y.M. 67/302; Indian village, 8.VII.1967 Y.M. 67/301.

All the collections are from conifers, mostly Picea mariana.

\section{Leotiaceae}

Bisporella citrina (Fr.) Korf \& Carp.

Que. Schefferville, John Lake, decaying wood, $550 \mathrm{~m}$, 30.VIII.1979 S.H. \& L.K.

Chlorociboria aeruginosa (Fr.) Ram., Korf \& Bat.

Nfld. Schefferville, Ruth Ridge, subalpine region, 9.VII.1967 E.K. - Que. Schefferville, Attikamagen Lake, on decaying wood, 500 m, 5.VIII.1967 Y.M. 67/1433.

The apothecia have coiled tomentum hyphae, covered with small crystals, which clearly separate this species from Chlorociboria aeruginascens (Nyl.) Ram., Korf \& Bat., as indicated by Dixon (1974).
Cudonia circinans (Fr.) Fr.

Nfld. Schefferville, Lejeune Lake, 550 m, 24.VIII.1979 S.H. \& L.K.

The asci, ca. $109(-126) \times 8.9 \mu \mathrm{m}$, and the apically enlarged paraphyses separate $C$. circinans from the next species.

\section{Cudonia confusa Bres.}

Nfld. Schefferville, Astray Lake, by a brook, $550 \mathrm{~m}, 4$.VIII. 1967 H.H. - Que. Schefferville, Dolly Lake, moist Picea mariana site, $550 \mathrm{~m}, 14$.VIII.1979 S.H. \& L.K.

Asci ca. $118 \times 9.2 \mu \mathrm{m}$, paraphyses not enlarged at the tip (cf. Ohenoja 1975).

Cyathicula cyathoidea (Merát) Thüm.

Nfld. Schefferville, Astray Lake, on stems of Heracleum maximum, $550 \mathrm{~m}, 4$.VIII.1967 Y.M. 67/1369.

The stalked apothecia, ca. $1 \mathrm{~mm}$ across, are brownish when dried. Excipulum with gelatinized walls. Asci $40 \times 4 \mu \mathrm{m}$, spores irregularly biseriate, fusoid, $6-9$ $\times 1.5-2 \mu \mathrm{m}$, no oil globules seen (cotton blue). Paraphyses $1.5 \mu \mathrm{m}$ thick.

Encoelia furfuracea (Pers.) Karst.

Nfld. Schefferville, Marble Lake, on Alnus, $450 \mathrm{~m}$, 12.VII.1967 P.K., 13.VII.1967 H.H. \& E.K. - Que. Fort Chimo, Highfall Creek, on Alnus, 50 m, 2.VIII.1967 H.H.

Also reported by Kallio (1980) from Esker and Churchill Falls - Twin Falls.

\section{Tympanis abietina Groves}

Que. Schefferville, Attikamagen Lake, on Abies balsamea, 500 m, 5.VIII.1967 Y.M. 67/1431a.

Mature asci $70-85 \times 11-12 \mu \mathrm{m}$, primary ascospores irregularly fusoid, $6-11 \times 1.5-2.0 \mu \mathrm{m}$, budding from these numerous allantoid secondary ascospores.

According to Groves (1952), there are two species of Tympanis on Abies spp. The other species, T. truncatula (Fr.) Rehm, has larger asci and its primary ascospores are broadly ellipsoid to subglobose.

Acknowledgements. I am especially grateful to Prof. Paavo Kallio, who enabled me to accomplish this study, and to the following persons, who helped by checking some determinations or made valuable field notes: Dr. Harri Harmaja, Miss Heli Heikkilä, Lic.Phil., Mr. Lasse Kosonen, Dr. Yrjö Mäkinen and Mrs. Esteri Ohenoja, Lic.Phil.

\section{References}

Bigelow, H.E. 1959: Notes on fungi from northern Canada 4. Tricholomataceae. - Can. J. Bot. 37: 769-779

Denison, W.C. 1959: Some species of the genus Scutellinia. - Mycologia 51: 605-635.

Dennis, R.W.G. 1949: A revision of the British Hyaloscyphaceae with notes on related European species. - Mycol. Pap. 32: 1-97.

Dennis, R.W.G. \& Itzerott, H. 1973: Octospora and Inermisia in Western Europe. - Kew Bull. 28: 5-23. 
Dharne, C.G. 1965: Taxonomic investigations on the discomycetous genus Lachnellula Karst. - Phytopathol. Zeitschr. 53: 101-144.

Dixon, J.R. 1974: Chlorosplenium and its segregates 2. The genera Chlorociboria and Chloroencoelia. - Mycotaxon 1: $193-237$.

Eckblad, F.-E. 1968: The genera of the operculate Discomycetes. A re-evaluation of their taxonomy, phylogeny and nomenclature. - Nytt Mag. Bot. 15: 1-191.

Elliott, M.E. \& Kaufert, M. 1974: Peziza badia and Peziza badioconfusa. - Can. J. Bot 52: 467-472.

Ginns, J. 1980: Peziza badioconfusa. - Fungi Canadenses 168 .

Groves, W.J. 1952: The genus Tympanis. - Can. J. Bot. 30: $571-651$.

Groves, W.J. \& Elliott, M.E. 1971: Notes on fungi from Northern Canada 6. Additional records of Discomycetes. - Ann. Univ. Turku (A II) 47 (Rep. Kevo Subarctic Sta. 8): $22-30$

Groves, W.J. \& Hoare, S.C. 1954: Notes on fungi from Northern Canada 1. Hypocreales and Discomycetes. Can. Field-Nat. 68: $1-8$

Harmaja, H. 1969: A neglected species, Gyromitra ambigua (Karst.) Harmaja, n. comb., and G. infula s. str. in Fennoscandia. - Karstenia 9: 13-19.

- 1973: Amendments of the limits of the genera Gyromitra and Pseudorhizina, with the description of a new species, Gyromitra montana. - Karstenia 13: 48-58.

- 1979: Notes on Gyromitra esculenta coll. and G. recurva, a noteworthy species of western North America. -Karstenia 19: $46-49$.

Heikkilä, H. \& Kallio, P. 1969: On the problem of subarctic basidiolichens 2. - Ann. Univ. Turku (A II) 40 (Rep. Kevo Subarctic Sta. 4): 90-97.

Hustich, I. 1949: On the forest geography of the Labrador peninsula. A preliminary synthesis. - Acta Geographica 10: 1-63.

Itzerott, H. 1977: The genus Octospora and an attempt to solve its taxonomic problems. - Kew Bull. 31: 497-500

Kallio, P. 1980: Some observations on the fungi of the central Quebec-Labrador peninsula. - McGill Subarctic Res. Pap. 30: 1-16.
Kankainen, E. 1969: On the structure, ecology and distribution of the species of Mitrula s.lat. - Karstenia 9: 2334

Karsten, P.A. 1869: Monographia Pezizarum fennicarum. Not. Sällsk. Fauna Flora Fenn. 10: 101-206

Korf, R.P. 1973: Discomycetes and Tuberales. - In: Ainsworth, G.C. (ed.), The fungi, an advanced treatise, 4A: 249-319. New York.

Nannfeldt, J.A. 1942: Contributions to the mycoflora of Sweden 6. On some white-excipled lignicolous or corticolous species of Lachnum Retz. ex Karst. - Svensk Bot. Tidskr. 36: 287-300.

Ohenoja, E. 1975: Leotia, Cudonia, Spathularia and Neolecta (Ascomycetes) in Finland. - Ann. Bot. Fenn. 12: $123-130$.

Ohenoja, E. \& Isoviita, P. 1981: Nomenclatural notes on Spathularia rufa (Ascomycotina, Geoglossaceae). Manuscript.

Raschle, P. 1978: Neufunde und Neukombinationen von Hyaloscyphaceae Nannfeldt (Helotiales). — Nova Hedwigia 30: $653-672$.

Raitviir, A. 1970: Synopsis of the Hyaloscyphaceae. - Scripta Mycol. 1: $1-115$.

Redhead, S.A. 1977: The genus Neolecta (Neolectaceae fam. nov., Lecanorales, Ascomycetes) in Canada. - Can. J. Bot. 55: 301-306.

Rifai, M.A. 1968: The Australasian Pezizales in the herbarium of the Royal Botanic Gardens Kew. - Verh. Kon. Ned. Acad. Wetensch., Afd. Natuurk. 2, 57: 1-295.

Schumacher, T. 1979: Notes on taxonomy, ecology, and distribution of operculate discomycetes (Pezizales) from river banks in Norway. - Norw. J. Bot. 26: 53-83.

Seaver, F.J. 1961a: The North American cup-fungi (Operculates). Supplemented ed. $-377 \mathrm{pp}$. New York.

- 1961b: The North American cup-fungi (Inoperculates). Supplemented ed. -428 pp. New York.

Svrček, M. 1969: Nové rody operkulátnich diskomycetu (Pezizales). Neue Gattungen operculater Discomyceten. - Ceská Mykol. 23: 83-96.

Weber, N.S. 1972: The genus Helvella in Michigan. - Michigan Bot. 11: 147-201.

Accepted for publication

on October 28,1981 